\title{
Lingkungan Kerja Auditor Dan Pilihan Karirnya Sebagai Auditor: Perspektif Mahasiswa Akuntansi
}

\author{
Sarwenda Biduri \\ Fakultas Ekonomi Dan Bisnis, Universitas Muhammadiyah Sidoarjo, Indonesia \\ Email: sarwendahbiduri@yahoo.com
}

\begin{abstract}
Abstrak
Penelitian ini bertujuan untuk menguji dan mendapatkan bukti empiris mengenai Persepsi Mahasiswa reguler dan non reguler prodi akuntansi Fakultas Ekonomi dan Bisnis Universitas Muhammadiyah Sidoarjo mengenai lingkungan kerja auditor dan pilihan karirnya sebagai auditor. Penelitian ini termasuk jenis penelitian kuantitatif. Data yang terkumpul diperoleh melalui penyebaran kuesioner kepada 70 responden, yaitu mahasiswa aktif semester 5 dan 7. Alat analisis yang digunakan adalah analisis uji normalitas dan uji t independent sampel-test dengan menggunakan program aplikasi SPSS versi 19.0. Hasil penelitian ini adalah terdapat perbedaan persepsi mahasiwa non reguler maupun reguler jurusan akuntansi mengenai lingkungan kerja auditor di Fakultas Ekonomi dan Bisnis Universitas Muhammadiyah Sidoarjo dan terdapat perbedaan persepsi mengenai pilihan karirnya sebagai auditor antara mahasiwa non reguler maupun reguler jurusan akuntansi di fakultas ekonomi dan bisnis universitas muhammadiyah Sidoarjo.
\end{abstract}

Kata kunci : Lingkungan Kerja, Pilihan Karir dan Auditor

\begin{abstract}
This study attempts to try and get empirical evidence perceptions regular students and non regular accounting prodi school of economics and business muhammadiyah university sidoarjo about auditor work environment on their carrier choice as auditors. This research kind of quantitative research The data that had been collected were obtained through distributing questionnaires to 70 redpondents who were student active first half of 5 and 7 gasal 2016-2017 force. This study used analytics normality and the test t independent sampeltest with on the spss version 19 for windows. The result of the research there is a difference of the perceptions student non regular or regular accounting of auditors about the auditor work environment at the economic and business muhammadiyah university sidoarjo with differences a perception of his career as auditors choice between student regular or regular non of accounting in school of economics and business Muhammadiyah University Sidoarjo.
\end{abstract}

Keywords: Perception, Auditor Work Environment, Their Carrier Choice 


\section{Pendahuluan}

Dalam memilih antar karir di bidang akuntansi, seorang mahasiswa harus tahu kekuatan dan kelemahan yang dimilikinya, dengan begitu, karir dapat dipilih sesuai dengan kemampuan seseorang. Karir merupakan suatu pilihan yang paling penting dalam menenetukan keberhasilan mahasiswa di masa mendatang. Oleh karena itu jika ada kesulitan dalam menentukan karir dapat mengakibatkan mahasiswa bingung dalam menentukan profesi yang tepat untuk masa depannya, khususnya mahasiswa yang telah lulus S1. Jenis profesi dalam bidang akuntansi ada berbagai macam, bidang diantaranya yaitu, bidang pendidikan, sektor publik, keuangan, manajemen, audit serta perpajakan. Dengan bertambahnya populasi mahasiswa dan semakin bertambahnya profesi akuntan membuat mahasiswa bingung untuk memilih profesi yang tepat, sehingga mahasiswa cenderung bingung dalam menentukan karirnya. Berkarir sebagai seorang akuntan sangatlah penting karena karena kegiatan akuntansi menghasilkan laporan keuangan yang nantinya laporan keuangan tersebut dapat digunakan untuk berbagai pihak dalam membuat keputusan. Oleh karena itu profesi sebagai akuntan sangat dibutuhkan dalam setiap organisasi bisnis.

Karir dapat ditentukan oleh setiap individu dengan melihat bagaimana kemampuan, bakat, minat atau kecerdasan serta ekspektasi yang akan dicapai oleh seorang individu di masa yang akan datang. Menurut Corawettoen ( 2013) "Kemampuan dan keahlian khusus yang dimiliki oleh suatu profesi adalah suatu keharusan agar profesi tersebut mampu bersaing di dunia usaha sekarang ini”. Pemilihan karir yang sesuai dengan bidang ilmu yang dimiliki tiap individu akan sangat mempengaruhi masa depannya di masa nendatang, dengan pemilihan karir yang sesuai dengan bidang ilmu yang dimiliki tiap individu akan mempermudah mereka menentukan pemnambilan keputusan tentang masa depannya di masa yang akan datang dengan tepat, hal ini sesuai dengan the right man the right place.

Profesi akuntan sangat penting karena dari kegiatan akuntansi akan dapat menghasilkan laporan keuangan yang nantinya laporan keuangan tersebut dapat 
diguanakan berbagai pihak dalam membuat keputusan. Profesi akuntan sangat penting dalan organisasi bisnis. Menurut Bashori (2013) "Persepsi adalah suatu proses dimana seseorang mengorganisasi, menginterpretasi, mengalami, dan mengolah sesuatu yang konkret ataupun abstrak yang diterima dari lingkungan eksternal yang nantinya dapat mempengaruhi perilaku seseorang". Kebanyakan orang bertindak atas dasar persepsi mereka dengan mengabaikan apakah persepsi itu mencerminkan keyakinan yang sebenarnya. Berdasarkan fenomena-fenomena tersebut maka penulis mencoba untuk melakukan penelitian mengenai pengaruh persepsi mahasiswa akuntansi mengenai lingkungan kerja auditor terhadap pemilihan karir sebagai auditor.

Auditor merupakan individu yang bertanggungjawab terhadap pemeriksaan atas kewajaran informasi keuangan entitas. Laporan auditor bermanfaat bagi banyak pihak untuk menilai perusahaan. Auditor harus memiliki pengetahuan memadai tentang akuntansi dan pemeriksaan informasi keuangan.

Dengan informasi yang diterima mahasiwa akuntansi mengenai profesi auditor maka akan menjadi salah satu pertimbangan mahasiswa memilih karir sebagai seorang auditor. Profesi sebagai seorang auditor mengindikasikan tidak terlepas dari sisi positif dan negatif. Untuk sisi positif, profesi ini merupakan pemberian jasa dengan mendapatkan imbalan atau honor yang tinggi, sebaliknya untuk sisi negatif diantaranya rutinitas yang tinggi, tekanan dari pihak internal atau eksternal, tingkat persaingan yang tinggi, dengan adanya kedua sisi tersebut, tidak menutup kemungkinan karir sebagai seorang auditor tidak akan dipilih oleh calon- calon lulusan S1 Akuntansi, sehingga profesi sebagai auditor akan kehilangan calon auditor yang berkualitas yang nantinya lebih memilih profesi lain sebagai karirnya.

Menurut Sunyoto (2014:43) "Lingkungan kerja adalah segala sesuatu yang ada di sekitar para pekerja dan yang dapat mempengaruhi dirinya dalam menjalankan tugastugas yang dibebankan, misalnya kebersihan, musik, penerangan dan lain-lain ". Menurut Suyono (2014) " Lingkungan kerja dipertimbangkan dalam pemilihan profesi mahasiswa terutama pada sifat pekerjaan yang rutin." 
Lingkungan kerja auditor sangat penting bagi mahasiswa khususnya jurusan akuntansi dalam pemilihan karirnya sebagai seorang auditor. Lingkungan kerja mengindikasikan suasana kerja yang kondusif antar komponen dalam suatu organisasi atau perusahaan, yang meliputi sifat kerja, rutinitas yang tinggi, tekanan dari pihak internal atau eksternal, tingkat persaingan yang tinggi dalam suatu pekerjaan yang merupakan indikator dari lingkungan kerja dimana seseorang berkarir.

Karir dapat diartikan suatu jabatan atau kedudukan atas suatu profesi yang dimiliki seseorang dalam suatu organisasi atau perusahaan tertentu, yang kedudukan tersebut memiliki tanggung jawab yang lebih tinggi dari sebelumnya. Menurut Nuraini (2013) "Pilihan karir dipengaruhi oleh stereotype yang dibentuk oleh seseorang tentang berbagai macam karir". Dalam menentukan pilihan pekerjaan, seorang individu akan mempertimbangkan nilai-nilai kebutuhan tertentu untuk mendapatkan kepuasan. Maka dengan itu, setiap individu akan mencari pekerjaan yang dapat memberikan kepuasan pada dirinya seperti yang diinginkan. Menurut Maya (2013), " Pilihan karir sebagai seorang akuntan publik sangat diharapkan oleh mahasiswa dengan harapan mendapatkan penghargaan secara finansial secara jangka panjang, adanya kenaikan gaji dan gaji yang tinggi".

Akuntan Publik yaitu akuntan yang memberikan jasa untuk mendapatkan imbalan atau honor ( $f e e$ ). Akuntan publik, seorang akuntan dapat melakukan praktek baik secara individu maupun sebagai anggota kantor akuntan publik. Profesi ini dijalankan guna memenuhi kebutuhan para pengguna, diantaranya kreditur, investor, dan instansi pemerintah. Menurut Setiawan (2012), "Untuk menjadi seorang akuntan publik diperlukan pelatihan kerja secara maksimal karena lingkungan kerja yang variatif". Auditor adalah seseorang dengan kualifikasi tertentu yang memberikan jasanya untuk mendapatkan imbalan atau honor.

Berdasarkan berbagai pendapat tersebut di atas, bahwa persepsi pada hakikatnya merupakan proses pengamatan seseorang melalui alat indranya terhadap suatu obyek, peristiwa tertentu, hasil pengamatan tersebut secara sadar dilakukan sehingga seseorang dapat memberi makna terhadap objek atau peristiwa yang diamatinya 
tersebut. Persepsi seseorang akan sangat mempengaruhi proses belajar atau minta/ bakat dan mendorong mahasiswa untuk melaksanakan motivasi belajarnya.

Berdasarkan latar belakang yang telah kemukakan sebelumnya, maka rumusan masalah dalam penelitian ini adalah, apakah terdapat perbedaan persepsi antara mahasiswa akuntansi regular dan mahasiswa non reguler di Universitas Muhammadiyah Sidoarjo mengenai lingkungan kerja auditor dan pilihan karirnya sebagai auditor. Sedangkan untuk tujuan penelitian ini yaitu, untuk menguji apakah terdapat perbedaan persepsi antara mahasiswa akuntansi reguler dan mahasiswa non reguler di Universitas Muhammadiyah Sidoarjo mengenai lingkungan kerja auditor dan pilihan karirnya sebagai auditor.

\section{Metode Penelitian}

\section{Jenis penelitian}

Penelitian kuantitaif adalah metode penelitian yang berlandaskan pada filsafat positivism, digunakan untuk meneliti pada populasi atau sampel tertentu, teknik pengambilan sampel dilakukan secara random, pengumpulan data menggunakan instrument penelitian analisis data bersifat kuantitaif atau statistik dengan tujuan untuk menguji hipotesis yang telah ditetapkan (Sugiyono, Metode Penelitian Bisnis , 2012). Jenis penelitian ini adalah kuantitif, karena penelitian ini mengambil sampel dari suatu populasi dan menggunakan kuesioner sebagai alat pengumpul data utamanya.

\section{Populasi dan Sampel}

Obyek dalam penelitian ini adalah mahasiswa Prodi Akuntansi Fakultas Ekonomi dan Bisnis Universitas Muhammadiyah Sidoarjo yang masih aktif semester 5 dan 7 tahun akademik gasal 2016/2017, dengan alasan bahwa pada semester tersebut sedang dan telah menempuh mata kuliah auditing. 


\section{Teknik Pengumpulan Data}

\section{Tinjauan kepustakaan (library research)}

yaitu mempelajari literatur-literatur, referensi dan catatan-catatan yang berhubungan dengan permasalahan yang dibahas guna memperoleh kerangka teoritis sekaligus sebagai rerangka dasar dan alat analisa.

Kuesioner, yaitu dengan mengajukan serangkaian pertanyaan yang dibuat dalam suatu daftar pertanyaan-pertanyaan yang akan diajukan kepada responden.

\section{Teknik Analisis}

\section{Uji Validitas,}

Instrumen yang digunakan dalam penelitian ini berbentuk kuesioner, sehingga pengujian validitas yang digunakan berupa validitas isi (content validity). Perhitungan ini akan dilakukan dengan bantuan program SPSS yang ditunjukkan jika item pertanyaan dinyatakan valid jika mempunyai nilai $r$ lebih besar dari 0,30 , sebaliknya jika item pertanyaan tidak valid mempunyai nilai r lebih kecil dari 0,30 (Sugiyono, 2012).

\section{Uji Reliabilitas}

pengujian ini bertujuan untuk mengukur keandalan dari instrument pengukur. Uji reliabilitas dalam penelitian ini menggunakan teknik Cronbach Alpha, dengan program SPSS versi 19.0. Koefisien cronbach alpha lebih besar dari 0,6 menunjukkan keandalan (reliabilitas) instrumen.

\section{Uji Hipotesis}

pengujian paired sample $t$-tes digunakan dalam penelitian ini untuk mengetahui perbedaan antara dua variabel yaitu persepsi mengenai lingkungan kerja auditor dan persepsi mengenai pilihan karirnya sebagai auditor yang ditunjukkan dalam pengambilan keputusan sebagai berikut :

1. Probabilitas sig $>0,05$ maka Ho diterima berarti tidak terdapat perbedaan persepsi antara mahasiswa akuntansi reguler dan mahasiswa non reguler Jurusan Akuntansi Fakultas Ekonomi dan Bisnis di Universitas Muhammadiyah Sidoarjo. 
2. Probabilitas sig < 0,05 Ho ditolak berarti terdapat perbedaan persepsi antara mahasiswa akuntansi reguler dan mahasiswa non reguler Jurusan Akuntansi Fakultas Ekonomi dan Bisnis di Universitas Muhammadiyah Sidoarjo.

\section{Hasil Dan Pembahasan}

Salah satu analisis yang digunakan dalam penelitian ini adalah analisis deskriptif. Analisis deskriptif digunakan untuk menguraikan tentang karakteristik dari suatu keadaan atau objek yang diteliti. Analisis ini mengemukakan data-data responden seperti karakteristik responden. Responden yang diambil untuk penelitian ini sebanyak 70 mahasiswa akuntansi, yang terdiri dari 35 mahasiswa kelas reguler dan 35 mahasiswa kelas non reguler. Cara pengumpulan data yang telah dijelaskan sebelumnya menghasilkan tingkat pengembalian kuesioner sebagaimana disebutkan dalam tabel berikut :

Tabel 1

Rincian Pengembalian Kuesioner

\begin{tabular}{|c|c|c|c|c|c|}
\hline $\begin{array}{c}\text { Kelompok } \\
\text { Responden }\end{array}$ & $\begin{array}{c}\text { Kuesioner } \\
\text { Disebar }\end{array}$ & $\begin{array}{c}\text { Kuesioner } \\
\text { Kembali }\end{array}$ & $\begin{array}{c}\text { Tingkat } \\
\text { Pengembalian }\end{array}$ & $\begin{array}{c}\text { Kuesioner } \\
\text { Gugur }\end{array}$ & $\begin{array}{c}\text { Kuesioner } \\
\text { Diolah }\end{array}$ \\
\hline $\begin{array}{c}\text { Mahasiswa } \\
\text { Akuntansi }\end{array}$ & 100 & 70 & $70 \%$ & - & 70 \\
$\begin{array}{c}\text { Reguler dan } \\
\text { Non Reguler }\end{array}$ & & & & & \\
\hline
\end{tabular}

Sumber: data primer diolah

Adapun rincian kuesioner yang kembali yang dilihat dari sudut pandang jenis kelamin, umur dan semester yang di tunjukkan dalam tabel berikut : 


\section{Mahasisiwa Non Reguler}

Tabel 2

Analisis Crosstab

\begin{tabular}{|c|c|c|c|c|}
\hline \multicolumn{5}{|c|}{ Count } \\
\hline & & \multicolumn{2}{c|}{ Umur } & Total \\
\hline \multirow{2}{*}{ Jenis Kelamin } & laki-laki & 6 & 14 & $\begin{array}{c}\text { Jenis } \\
\text { Kelamin }\end{array}$ \\
\cline { 2 - 5 } & Perempuan & 10 & 5 & \\
\hline \multicolumn{2}{|c|}{ Total } & 16 & 19 & 35 \\
\hline \multicolumn{2}{|c|}{} & & & \\
\hline
\end{tabular}

\section{Sumber: data primer diolah}

Berdasarkan hasil analisis crosstab yang ditunjukkan pada tabel diatas dapat dijelaskan bahwa mahasiswa Non reguler yang digunakan sebagai responden berjumlah 35 responden dimana reponden yang berjenis kelamin laki-laki sebanyak 6 orang yang memiliki usia 21 Tahun dan sisanya responden berjenis kelamin laki-laki sebanyak 14 orang yang memiliki usia 22-25 Tahun, sedangkan responden yang berjenis kelamin perempuan sebanyak 10 orang yang memiliki usia 21 Tahun dan sisanya berjenis kelamin perempuan sebanyak 5 orang yang memiliki usia 22-25 Tahun.

Tabel 3

Hasil Pengujian Chi Square

\begin{tabular}{|c|c|c|c|}
\hline & Value & Df & $\begin{array}{l}\text { Asymp. Sig. } \\
\text { (2-sided) }\end{array}$ \\
\hline Pearson Chi-Square & $4.644^{\mathrm{a}}$ & & .031 \\
\hline Continuity Correctionb & 3.284 & & .070 \\
\hline Likelihood Ratio & 4.733 & & .030 \\
\hline Fisher's Exact Test & & & \\
\hline $\begin{array}{l}\text { Linear-by-Linear } \\
\text { Association }\end{array}$ & 4.511 & & .034 \\
\hline $\mathrm{N}$ of Valid Cases ${ }^{b}$ & 35 & & \\
\hline
\end{tabular}

Sumber: Data Diolah

Berdasarkan hasil pengujian Chi Square pada tabel diatas dapat ditunjukkan bahwa nilai Sig yang diperoleh sebesar $0.031<0.05$. hal ini dapat diartikan bahwa Ho ditolak yang dapat diartikan bahwa terdapat hubungan yang signifikan antara jenis 
kelamin dengan usia dimana jenis kelamin mahasiswa FEB Universitas Muhammadiyah Sidoarjo Jurusan Akuntansi mempunyai korelasi dengan usia. Memang dilihat secara nyata bahwa profesi akuntan dapat ditentukan oleh setiap individu dengan melihat bagaimana kemampuan, bakat, minat atau kecerdasan serta ekspektasi yang akan dicapai oleh seorang individu dimana dilihat dari usia dan jenis kelamin karena keuletan seorang perempuan di banding laki-laki sangat berpengaruh begitu juga dengan usia akan mempengaruhi kecekatan dan perkembangan ilmu karena di Fakultas Ekonomi dan Bisnis Universitas Muhammadiyah Sidoarjo Jurusan Akuntansi mayoritas mahaiswa non reguler bekerja pada profesi akuntansi.

Tabel 4

Analisis Crosstab

\begin{tabular}{|l|l|r|r|r|}
\hline \multicolumn{5}{|c|}{ Count } \\
\hline & & \multicolumn{2}{c|}{ Semester } & \multirow{2}{*}{ Total } \\
\hline & & Semester 5 & Semester 7 & \multicolumn{1}{c|}{ 20 } \\
\hline Jenis Kelamin & laki-laki & 13 & 7 & 15 \\
\cline { 2 - 5 } & Perempuan & 13 & 2 & 35 \\
\hline Total & 26 & 9 & \\
\hline
\end{tabular}

Sumber: data primer diolah

Berdasarkan hasil analisis crosstab yang ditunjukkan pada tabel diatas dapat dijelaskan bahwa mahasiswa Non reguler yang digunakan sebagai responden berjumlah 35 responden dimana reponden yang berjenis kelamin laki-laki sebanyak 13 orang yang menduduki semester 5 dan sisanya responden berjenis kelamin laki-laki sebanyak 7 orang yang menduduki semester 7, sedangkan responden yang berjenis kelamin perempuan sebanyak 13 orang yang menduduki semester 5 dan sisanya berjenis kelamin perempuan sebanyak 2 orang yang menduduki semester 7. 
Tabel 5

Hasil Pengujian Chi Square

\begin{tabular}{|c|c|c|c|}
\hline & Value & Df & $\begin{array}{l}\text { Asymp. Sig. (2- } \\
\text { sided) }\end{array}$ \\
\hline Pearson Chi-Square & $2.106^{\mathrm{a}}$ & 1 & .147 \\
\hline Continuity Correction ${ }^{b}$ & 1.125 & 1 & .289 \\
\hline Likelihood Ratio & 2.225 & 1 & .136 \\
\hline Fisher's Exact Test & & & \\
\hline $\begin{array}{l}\text { Linear-by-Linear } \\
\text { Association }\end{array}$ & 2.046 & 1 & .153 \\
\hline $\mathrm{N}$ of Valid Cases ${ }^{\mathrm{b}}$ & 35 & & \\
\hline
\end{tabular}

\section{Sumber: Data Diolah}

Berdasarkan hasil pengujian Chi Square pada tabel diatas dapat ditunjukkan bahwa nilai Sig yang diperoleh sebesar $0.147>0.05$ hal ini dapat diartikan bahwa Ho diterima yang dapat diartikan bahwa tidak terdapat hubungan yang signifikan antara jenis kelamin dengan semester dimana jenis kelamin mahasiswa FEB Universitas Muhammadiyah Sidoarjo Jurusan Akuntansi tidak mempunyai korelasi dengan semester yang di duduki. Memang dilihat secara nyata bahwa Profesi akuntan tidak berpengaruh terhadap kedudukan semester yang telah di tempuh karena mahasiswa non reguler ini banyak sekali yang sudah bekerja di lingkungan kerja auditor dan pilihan karirnya sebagai auditor dimana kuliah hanya penunjang jabatan saja.

\section{Mahasiswa Reguler}

Tabel 6

Analisis Crosstab Mahasiswa Reguelr

\begin{tabular}{|l|l|r|r|r|}
\hline \multicolumn{5}{|c|}{ Count } \\
\hline & & \multicolumn{2}{c|}{ Umur } & \multirow{2}{*}{ Total } \\
\hline \multirow{2}{*}{ Jenis Kelamin } & & 21 Tahun & $22-25$ Tahun & 21 \\
\cline { 2 - 5 } & Perempuan & 7 & 14 & 14 \\
\cline { 2 - 4 } Total & 9 & 5 & 35 \\
\hline
\end{tabular}

\section{Sumber: data primer diolah}

Berdasarkan hasil analisis crosstab yang ditunjukkan pada tabel diatas dapat dijelaskan bahwa mahasiswa reguler yang digunakan sebagai responden berjumlah 35 
responden dimana reponden yang berjenis kelamin laki-laki sebanyak 7 orang yang memiliki usia 21 Tahun dan sisanya responden berjenis kelamin laki-laki sebanyak 14 orang yang memiliki usia 22-25 Tahun, sedangkan responden yang berjenis kelamin perempuan sebanyak 9 orang yang memiliki usia 21 Tahun dan sisanya berjenis kelamin perempuan sebanyak 5 orang yang memiliki usia 22-25 Tahun.

\section{Tabel 7}

\section{Hasil Pengujian Chi Square}

\begin{tabular}{|c|c|c|c|}
\hline & Value & Df & $\begin{array}{l}\text { Asymp. Sig. (2- } \\
\text { sided) }\end{array}$ \\
\hline Pearson Chi-Square & $3.532^{\mathrm{a}}$ & 1 & .121 \\
\hline Continuity Correction b & 3.254 & 1 & .050 \\
\hline Likelihood Ratio & 4.833 & 1 & .020 \\
\hline Fisher's Exact Test & & & \\
\hline $\begin{array}{l}\text { Linear-by-Linear } \\
\text { Association }\end{array}$ & 4.421 & 1 & .025 \\
\hline $\mathrm{N}$ of Valid Cases ${ }^{b}$ & 35 & & \\
\hline
\end{tabular}

Sumber: Data Diolah

Berdasarkan hasil pengujian Chi Square pada tabel diatas dapat ditunjukkan bahwa nilai Sig yang diperoleh sebesar $0.121>0.05$. hal ini dapat diartikan bahwa Ho diterima yang dapat diartikan bahwa tidak terdapat hubungan yang signifikan antara jenis kelamin dengan usia dimana jenis kelamin mahasiswa FEB universitas muhammadiyah sidoarjo jurusan akuntansi tidak mempunyai korelasi dengan usia. Memang dilihat secara nyata bahwa Profesi akuntan dapat ditentukan oleh setiap individu dengan melihat bagaimana kemampuan, bakat, minat atau kecerdasan serta ekspektasi yang akan dicapai oleh seorang individu dimana dilihat dari usia dan jenis kelamin tetapi mahasiswa reguler ini masih belum memiliki pengalaman hanya saja memiliki teori saja dan belum bekerja di lingkungan kerja auditor dan pilihan karirnya sebagai auditor masih tergambar hanya $10 \%$ saja. 
Tabel 8

Analisis Crosstab

\begin{tabular}{|l|l|r|r|r|}
\hline \multicolumn{5}{|c|}{ Count } \\
\hline \\
\hline
\end{tabular}

Sumber: data primer diolah

Berdasarkan hasil analisis crosstab yang ditunjukkan pada tabel diatas dapat dijelaskan bahwa mahasiswa reguler yang digunakan sebagai responden berjumlah 35 responden dimana reponden yang berjenis kelamin laki-laki sebanyak 12 orang yang menduduki semester 5 dan sisanya responden berjenis kelamin laki-laki sebanyak 5 orang yang menduduki semester 7, sedangkan responden yang berjenis kelamin perempuan sebanyak 14 orang yang menduduki semester 5 dan sisanya berjenis kelamin perempuan sebanyak 4 orang yang menduduki semester 7.

\section{Tabel 9}

\section{Hasil Pengujian Chi Square}

\begin{tabular}{|c|c|c|c|}
\hline & Value & Df & $\begin{array}{l}\text { Asymp. Sig. (2- } \\
\text { sided) }\end{array}$ \\
\hline Pearson Chi-Square & $5.532^{\mathrm{a}}$ & 1 & .011 \\
\hline Continuity Correction ${ }^{b}$ & 4.124 & 1 & .020 \\
\hline Likelihood Ratio & 5.867 & 1 & .013 \\
\hline Fisher's Exact Test & & & \\
\hline Linear-by-Linear & 55 & 1 & 016 \\
\hline Association & & 1 & .010 \\
\hline $\mathrm{N}$ of Valid Casesb & 35 & & \\
\hline
\end{tabular}

Sumber: Data Diolah 
Berdasarkan hasil pengujian Chi Square pada tabel diatas dapat ditunjukkan bahwa nilai Sig yang diperoleh sebesar $0.01<0.05$ hal ini dapat diartikan bahwa Ho ditolak yang dapat diartikan bahwa terdapat hubungan yang signifikan antara jenis kelamin dengan semester dimana jenis kelamin mahasiswa FEB universitas muhammadiyah sidoarjo jurusan akuntansi mempunyai korelasi dengan semester yang di duduki. Memang dilihat secara nyata bahwa Profesi akuntan berpengaruh terhadap kedudukan semester yang telah di tempuh karena mahasiswa reguler ini memiliki ilmu yang masih alami dan perkembangan pengetahuan yang semakin berkembang hanya saja belum diterapkan di dunia kerja tetapi tidak menutup kemungkinan mesipun pengalaman yang di miliki masih belum ada akan tetapi ilmu yang dimiliki sudah berkembang sehingga jika mahasiswa bekerja di lingkungan kerja auditor dan pilihan karirnya sebagai auditor maka profesi ini akan mengantarkan mahsiswa akuntansi untuk berlomba-lomba memberikan jasa dengan mendapatkan imbalan atau honor yang tinggi, sebaliknya jika diantaranya rutinitas yang tinggi, tekanan dari pihak internal atau eksternal, tingkat persaingan yang tinggi, dengan adanya kedua sisi tersebut, tidak menutup kemungkinan karir sebagai seorang auditor tidak akan dipilih oleh calon- calon lulusan S1 Akuntansi, sehingga profesi sebagai auditor akan kehilangan calon auditor yang berkualitas yang nantinya lebih memilih profesi lain sebagai karirnya.

Berdasarkan hasil penelitian dapat ditunjukkan bahwa perhitungan uji ke validitas dari item pertanyaan di tunjukkan sebagai berikut:

\section{Mahasiswa Akuntansi Non Reguler}

Tabel 10

Uji validitas Kuisioner Mahasiswa Akuntansi Non Reguler

\begin{tabular}{|c|c|c|c|c|}
\hline No. & Item Pertanyaan & corrected item total correlation & $\mathrm{r}$ & Keterangan \\
\hline 1 & $\mathrm{X} 1.1$ & 0,743 & 0.30 & Valid \\
\hline 2 & $\mathrm{X} 1.2$ & 0,726 & 0.30 & Valid \\
\hline 3 & $\mathrm{X} 1.3$ & 0,552 & 0.30 & Valid \\
\hline 4 & $\mathrm{X} 2.1$ & 0,676 & 0.30 & Valid \\
\hline 5 & $\mathrm{X} 2.2$ & 0,724 & 0.30 & Valid \\
\hline 6 & $\mathrm{X} 2.3$ & 0,539 & 0.30 & Valid \\
\hline 7 & $\mathrm{X} 2.4$ & 0,357 & 0.30 & Valid \\
\hline
\end{tabular}

\section{Sumber: data diolah}


Berdasarkan tabel 10 diatas dapat dijelaskan bahwa semua item pertanyaan yang di jawab oleh mahasiswa akuntansi non reguler dapat diartikan valid karena nilai corrected item total correlation lebih besar dari 0,30 sehingga pertanyaan ini dapat di lanjutkan sebagi referensi peneliti lain.

\section{Mahasiswa Akuntansi Reguler}

Tabel 11

Uji validitas Kuisioner Mahasiswa Akuntansi Reguler

\begin{tabular}{|c|c|c|c|c|}
\hline No & Item Pertanyaan & corrected item total correlation & $\mathrm{r}$ & Keterangan \\
\hline 1 & $\mathrm{X} 1.1$ & 0,457 & 0.30 & Valid \\
\hline 2 & $\mathrm{X} 1.2$ & 0,712 & 0.30 & Valid \\
\hline 3 & $\mathrm{X} 1.3$ & 0,585 & 0.30 & Valid \\
\hline 4 & $\mathrm{X} 2.1$ & 0,651 & 0.30 & Valid \\
\hline 5 & $\mathrm{X} 2.2$ & 0,522 & 0.30 & Valid \\
\hline 6 & $\mathrm{X} 2.3$ & 0,492 & 0.30 & Valid \\
\hline 7 & $\mathrm{X} 2.4$ & 0,563 & 0.30 & Valid \\
\hline
\end{tabular}

\section{Sumber: data diolah}

Berdasarkan tabel 11 diatas dapat dijelaskan bahwa semua item pertanyaan yang di jawab oleh mahasiswa akuntansi reguler dapat diartikan valid karena nilai corrected item total correlation lebih besar dari 0,30 sehingga pertanyaan ini dapat di lanjutkan sebagi referensi peneliti lain.

Uji reliabilitas dimaksudkan untuk mengetahui sejauh mana hasil pengukuran tetap konsisten apabila dilakukan pengukuran dua kali atau lebih terhadap pernyataan yang sama menggunakan alat ukur yang sama pula. Pengujian reliabilitas bertujuan untuk mewujudkan sejauh mana suatu pengukuran relative yang ditunjukkan sebagai berikut:

Tabel 12

Uji Reliabilitas Kuisioner Mahasiswa Akuntansi Reguler \& Non Reguler

\begin{tabular}{|c|l|c|c|c|}
\hline No & \multicolumn{1}{|c|}{ Variabel } & Crombach Alpha & $\mathrm{R}$ & Keterangan \\
\hline 1 & $\begin{array}{l}\text { Persepsi mengenai } \\
\text { lingkungan kerja auditor } \\
\text { untuk mahasiswa Non } \\
\text { Reguler }\end{array}$ & 0,816 & 0.6 & Reliabel \\
\hline 2 & $\begin{array}{l}\text { Persepsi mengenai } \\
\text { pilihan karirnya sebagai } \\
\text { auditor untuk }\end{array}$ & 0,766 & 0.6 & Reliabel \\
\hline
\end{tabular}




\begin{tabular}{|c|l|c|c|c|}
\hline & mahasiswa non regular & & & \\
\hline 3 & $\begin{array}{l}\text { Persepsi mengenai } \\
\text { lingkungan kerja auditor } \\
\text { untuk mahasiswa } \\
\text { regular }\end{array}$ & 0,753 & 0,6 & Reliabel \\
\hline 4 & $\begin{array}{l}\text { Persepsi mengenai } \\
\text { pilihan karirnya sebagai } \\
\text { auditor untuk } \\
\text { mahasiswa regular }\end{array}$ & 0,755 & 0,6 & Reliabel \\
\hline
\end{tabular}

\section{Sumber: Data Diolah}

Berdasarkan table 12 dapat dijelaskan bahwa Koefisien cronbach alpha yang lebih besar dari 0,6 menunjukkan keandalan (reliabilitas) instrument pada setiap variabel Persepsi mengenai lingkungan kerja auditor dan Persepsi mengenai pilihan karirnya sebagai auditor.

Tabel 13

Uji Beda paired sample $t$ test

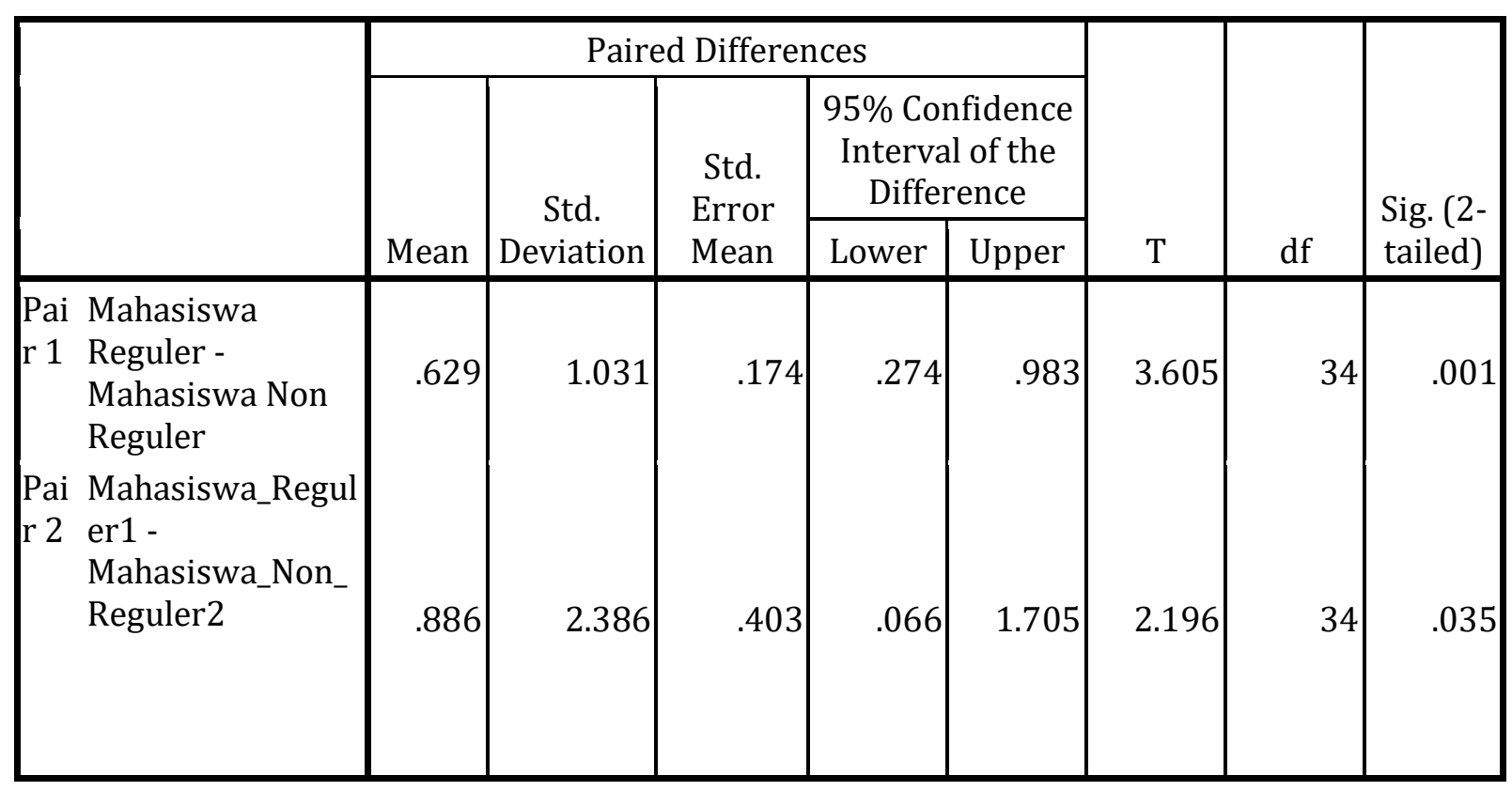

Sumber: Data Diolah

Berdasarkan tabel 13 diatas dapat dijelaskan bahwa terdapat perbedaan Persepsi mahasiwa non reguler maupun non reguler jurusan akuntansi mengenai lingkungan kerja auditor di fakultas ekonomi dan bisnis universitas muhammadiyah dengan nilai signifikan sebesar 0,001<0,05 dengan t-hitung $>$ t-table dimana 3,605>1,690. 
Sedangkan untuk Persepsi mengenai pilihan karirnya sebagai auditor juga mempunyai perbedaan antara mahasiwa non reguler maupun reguler jurusan akuntansi di fakultas ekonomi dan bisnis universitas muhammadiyah dengan nilai signifikan sebesar 0,035 $<0,05$ dengan t-hitung $>$ t-table dimana 2.196>1,690.

Berdasarkan hasil analisis diatas dapat di jelaskan dalam pembahasan ini menunjukkan bahwa terdapat perbedaan Persepsi mahasiwa non reguler maupun reguler jurusan akuntansi mengenai lingkungan kerja auditor di fakultas ekonomi dan bisnis universitas muhammadiyah dengan nilai signifikan sebesar 0,001<0,05 hal ini dapat diartikan bahwa adanya informasi negatif mengenai lingkungan kerja auditor mungkin dapat mengurangi minat mereka untuk memilih karir sebagai auditor dan mengalihkan pilihan karirnya ke profesi akuntansi yang lain sebaliknya jika adanya informasi positif mengenai lingkungan kerja auditor mungkin dapat meningkatkan minat mereka untuk memilih karir sebagai auditor dan mengalihkan pilihan karirnya ke profesi akuntansi yang lain. Dengan demikian, profesi auditor dapat kehilangan caloncalon auditor yang berkualitas. Tingkat perputaran kerja sangat menentukan kedudukan staf pada lingkungan kerja akuntan publik, sehingga bila tingkat perputaran kerja yang negatif akan menimbulkan dampak yang negatif pula yang jika tingkat perputaran kerja yang positif akan menimbulkan dampak yang positif pula. Sedangkan jika dilihat dari Persepsi mengenai pilihan karirnya sebagai auditor juga mempunyai perbedaan antara mahasiwa non reguler maupun reguler jurusan akuntansi di fakultas ekonomi dan bisnis universitas muhammadiyah dengan nilai signifikan sebesar 0,035 $<0,05$ hal ini dapat diartikan bahwa Dalam proses pemilihan karir, setiap individu akan selalu mempertimbangkan segala potensi, bakat/minat, kecerdasan maupun harapan yang akan dicapainya. Selain itu, seorang individu akan terlebih dahulu mengumpulkan berbagai informasi yang berkaitan dengan karir yang diinginkan. Informasi yang berguna dalam membuat pilihan karir ada tiga jenis, yaitu (1) informasi pribadi sosial, (2) informasi pendidikan, (3) informasi pekerjaan. 


\section{Kesimpulan Dan Saran}

\section{Kesimpulan}

Berdasarkan hasil analisis diatas dapat disimpulkan bahwa; Terdapat perbedaan persepsi mahasiwa non reguler maupun reguler jurusan akuntansi mengenai lingkungan kerja auditor di Fakultas Ekonomi dan Bisnis Universitas Muhammadiyah Sidoarjo. hal ini dapat diartikan bahwa adanya informasi negatif mengenai lingkungan kerja auditor mungkin dapat mengurangi minat mereka untuk memilih karir sebagai auditor dan mengalihkan pilihan karirnya ke profesi akuntansi yang lain, sebaliknya jika adanya informasi positif mengenai lingkungan kerja auditor mungkin dapat meningkatkan minat mereka untuk memilih karir sebagai auditor dan mengalihkan pilihan karirnya ke profesi akuntansi yang lain. Terdapat perbedaan persepsi mengenai pilihan karirnya sebagai auditor antara mahasiwa non reguler maupun reguler jurusan akuntansi di Fakultas Ekonomi dan Bisnis Universitas Muhammadiyah Sidoarjo. Hal ini dapat diartikan bahwa dalam proses pemilihan karir, setiap individu akan selalu mempertimbangkan segala potensi, bakat/minat, kecerdasan maupun harapan yang akan dicapainya.

\section{Saran}

Saran yang dapat penulis berikan dalam penelitian ini adalah Setiap indikator variabel yang digunakan dalam kuesioner sebaiknya menggunakan indikator lain yang baru yang sesuai dengan keadaan yang sebenarnya. Bagi peneliti selanjutnya untuk memperluas obyek penelitian. Hal ini diperlukan untuk meningkatkan akurasi hasil yang diperoleh dimasa yang akan datang dapat lebih sempurna dari penelitian ini.

\section{Daftar Pustaka}

Bashori, Akmal. 2013. Pendekatan Hermeneutika : Sebuah Paradigma Dan Kerangka Metodologi. Semarang. Institut Agama Islam Negeri Walisongo.

Corawettoeng, M. 2013. Pengaruh Persepsi Mahasiswa Akuntansi Mengenai Lingkungan Kerja Auditor Terhadap Pilihan Karirnya Sebagai Auditor (Studi Pada Mahasiswa Akuntansi Universitas Hasanuddin Dan Politeknik Negeri Ujung Pandang). 
Maya, S. 2013. Faktor-Faktor Yang Mempengaruhi Pemilihan Karir Menjadi Akuntan Publik Oleh Mahasiswa Departemen Akuntansi Fakultas Ekonomi UMSU Medan. Jurnal Riset Akuntansi Dan Bisnis Volume 3 Nomor 2 , 174-201.

Nuraini. 2013. Manajemen Sumber Daya Manusia. Aswaja Pressindo .

Setiawan, C. A. 2012. Analisis Faktor-Faktor Yang Mempengaruhi Pemilihan Karir Menjadi Akuntan Publik Oleh Mahasiswa Akuntansi. Jurnal ilmiah Akuntansi volume 1 nomor $1,53-58$.

Sugiyono. 2012. Metode Penelitian Bisnis. Bandung: Alfabet.

Sunyoto, Danang. 2014. Konsep Dasar Riset Pemasaran \& Perilaku Konsumen. Yogyakarta: CAPS

Suyono, Nanang Agus. 2014. Analisis Faktor-Faktor Yang Mempengaruhi Pemilihan Karir Sebagai Akuntan Publik (Studi Empiris Pada Mahasiswa Akuntansi UNSIQ. Jurnal PKM II (2014) 69-83 . ISSN: 2354-869X. 